\title{
FACTORS AFFECTING THE LETHALITY OF CAMPYLOBACTER FETUS SUBSPECIES JEJUNI IN MICE
}

\author{
D. E. S. Stewart-Tull, F. K. P. Ng and A. C. Wardlaw \\ Department of Microbiology, University of Glasgow, Alexander Stone Building, \\ Garscube Estate, Bearsden, Glasgow G61 1QH, Scotland
}

\begin{abstract}
SUMmaRY. Intraperitoneal injection of Campylobacter fetus ss. jejuni into $\mathrm{HAM} / 1 \mathrm{CR}$ mice was lethal, but viable counts of bacteria from whole body homogenates, organs and blood indicated that death was not due to sustained bacterial multiplication. Heat-killed organisms $\left(5 \times 10^{9} \mathrm{cfu}\right)$ injected into 7 -day-old mice caused death within $24 \mathrm{~h}$ and this was shown to be due to endotoxin. Both ferric iron and heterologous lipopolysaccharide enhanced virulence; the LD50 was lowered from $1.8 \times 10^{9} \mathrm{cfu}$ to $2.7 \times 10^{7} \mathrm{cfu}$ when both were used. Three-day-old or adult animals survived challenge with Campylobacter fetus without clinical symptoms when challenged orally or by intravenous or intraperitoneal routes.
\end{abstract}

\section{INTRODUCTION}

In 1946, Levy isolated from the diarrhoeal stools of patients suffering from gastro-enteritis, vibrio organisms which were similar to Vibrio jejuni from bovine diarrhoeal infections (Jones, Orcutt and Little, 1931). Vibrio jejuni was subsequently called Campylobacter fetus ss. jejuni (Smibert, 1978) and was implicated as the cause of a haemorrhagic diarrhoea in children (Middelkamp and Wolf, 1961; Wheeler and Borchers, 1961) and of acute enteritis in adults (Mandel and Ellison, 1963). Both $C$. fetus ss. jejuni and ss. intestinalis are now recognised as causing respiratory, vascular, nervous, gastro-intestinal and reproductive tract infections in man (Philip and Tilton, 1977). They cause haemorrhagic congestion and mucoid oedema of the intestinal mucosa (Lambert et al., 1979). Systemic infections in man are usually characterised by bacteraemia (Jackson, Hinton and Allison, 1960; Hallett, Botha and Logan, 1977; Guerrant et al., 1978; Robinson, 1978).

Procedures for isolating $C$. fetus ss. jejuni have been improved (Butzler et al., 1973; Skirrow, 1977) but it has been difficult to find a suitable animal model to study the pathogenesis of campylobacter enteritis (Prescott and Karmali, 1978; Butzler and Skirrow, 1979; Ng, 1981). Diarrhoea was induced in 3-day-old chickens after oral administration of $C$. fetus ss. jejuni $9 \times 10^{7} \mathrm{cfu} / \mathrm{ml}$ (Ruiz-Palacios, Escamilla and Torres, 1981) although other investigators have failed to confirm this (Manninen, Prescott and Dohoo, 1982). 
In the present investigation, the initial aim was to develop a mouse model to study campylobacter infection, but our results indicate that the lethality of $C$. fetus ss. jejuni for young mice is not directly correlated with the organism's replication in this host. Hence, the mouse is an unsuitable model of infection in man.

\section{MATERIALS AND METHODS}

Campylobacter strains. C. fetus ss. jejuni strain 5636 isolated from the stools of a child with diarrhoea was provided by Dr M. B. Skirrow, Worcester Royal Infirmary, Worcester. C. fetus ss. jejuni strain 4249 isolated from the stools of an adult with diarrhoea was provided by Dr T. F. Elias-Jones of the former City Laboratory, Glasgow.

Growth and harvesting of organisms. Bacteria were grown in Nutrient Broth No. 2 (Oxoid) $25 \mathrm{~g} / \mathrm{L}$ supplemented with yeast extract (Difco) $5 \mathrm{~g} / \mathrm{L}$ and L-cystine (Sigma Chemical Co., St Louis, MO) $0.2 \mathrm{~g} / \mathrm{L}$. This medium $(100 \mathrm{ml})$ was seeded with $10.0 \mathrm{ml}$ of a $24-\mathrm{h}$ starter culture grown in the same medium. Flasks were incubated in anaerobic jars in an atmosphere of $\mathrm{O}_{2} 5 \%$, $\mathrm{CO}_{2} 10 \%$, and $\mathrm{N}_{2} 85 \%$ (v/v) at $37^{\circ} \mathrm{C}$ on an orbital shaker set at $100 \mathrm{rpm}$ (L.H. Engineering, Stoke Poges, Bucks).

The organisms were removed from the medium by centrifugation at $12000 \mathrm{~g}$ for $15 \mathrm{~min}$ at $4^{\circ} \mathrm{C}$. The cell pellets were resuspended in $0.85 \%(\mathrm{w} / \mathrm{v})$ sterile physiological saline to provide the bacterial suspensions used in animal inoculations. The number of viable organisms in the inoculum was determined (Miles, Misra and Irwin, 1938) with 6.0\% horse-blood-agar plates (Columbia agar base $3.9 \mathrm{~g} / 100 \mathrm{ml}$ plus defibrinated horse blood $6 \mathrm{ml}$; Oxoid) incubated at $37^{\circ} \mathrm{C}$ in the atmosphere described above.

Heat treatment of $C$. fetus ss. jejuni cells. Samples of the bacterial suspension were heated at $100^{\circ} \mathrm{C}$ for $30 \mathrm{~min}$, centrifuged at $12000 \mathrm{~g}$ for $15 \mathrm{~min}$ at $4^{\circ} \mathrm{C}$ and the supernate removed aseptically. The killed organisms were resuspended in sterile physiological saline. The efficiency of heat treatment was checked by plating out the supernates and resuspended pellets and demonstrating sterility.

Sonication of C. fetus ss. jejuni cells. In order to obtain preparations containing cytoplasmic constituents or cell envelopes, a thick suspension of $C$. fetus organisms was treated in an M.S.E. ultrasonic machine for $5 \mathrm{~min}$ in an ice-bath. The sonicated cells were centrifuged at $12000 \mathrm{~g}$ for $15 \mathrm{~min}$ and the supernate and pellet were retained.

Mice. HAM/1CR mice (1-35-day-old) were obtained from the outbred colony in the Microbiology Animal Unit. Siblings were used from pens containing a single breeding pair. The animals were provided with a standard pelleted diet and water ad libitum.

Administration of $C$. fetus ss jejuni to mice. With 3-5-week-old mice, $0.5 \mathrm{ml}$ of the bacterial suspension was administered orally directly into the stomach through a nylon intravenous cannula (pink luer 3FG or green luer 2FG; Portex Ltd, Hythe, Kent). Intravenous (i.v.) injections $(0.2 \mathrm{ml})$ were given into the tail vein. For intraperitoneal (i.p.) challenge, a volume of $0.5 \mathrm{ml}$ was injected.

In delivering i.p. challenges, we took account of the small size of very young mice. A constant number of organisms was given to 1-3-day-old mice in $0.05 \mathrm{ml}$ and to 7-and 14-day-old mice in $0.1 \mathrm{ml}$ of the suspending fluid. This was achieved by standardisation against the 5 th International Opacity Reference Preparation designated as 10 International opacity units (o.u) and obtained from the World Health Organization, Laboratory for Biological Standards (N.I.B.S.C., Holly Hill, Hampstead, London). In our experience, 1 o.u. was equivalent to $1 \times 10^{9} \mathrm{cfu}$ of $C$. fetus ss. jejuni $/ \mathrm{ml}$.

Determination of numbers of viable $C$. fetus ss. jejuni organisms surviving in 7-day-old mice. Mice were killed by cervical dislocation at 12 -h intervals, washed in ethanol and blotted dry with paper tissue. With a mixer emulsifier (Silverson Machines Ltd, London), the whole body was minced and homogenised in $10.0 \mathrm{ml}$ of sterile saline to give a fine suspension. The homogenates were centrifuged for $10 \mathrm{~min}$ at $1500 \mathrm{~g}$ to remove large particles, and the number of viable C. fetus ss. jejuni cells in the supernate was determined; the values were expressed as cfu/mouse of $2.5 \mathrm{~g}$ average weight.

The selective medium for counting $C$. fetus ss. jejuni in the mouse homogenates was Columbia agar base plus $6 \%$ lysed blood, vancomycin $\mathrm{HCl} 10 \mu \mathrm{g} / \mathrm{ml}$ (Eli Lilly and Co. Ltd, 
Basingstoke, Hants), polymyxin B sulphate $2.5 \mathrm{IU} / \mathrm{ml}$ and trimethoprim lactate $5 \mu \mathrm{g} / \mathrm{ml}$ (Wellcome Reagents, Beckenham, Kent).

The effect of ferric ammonium citrate on C. fetus ss. jejuni in 7-day-old mice. A sterile solution of ferric ammonium citrate $2 \cdot 0 \mathrm{mg} / \mathrm{ml}$ ( $三 \mathrm{Fe}^{3+} 320 \mu \mathrm{g} / \mathrm{ml}$; BDH Chemicals Ltd, Poole, Dorset) in saline was prepared and different concentrations in $0.1 \mathrm{ml}$ were injected i.p. with the viable suspension of $C$. fetus ss. jejuni into 7-day-old mice. The mortalities were recorded during a 10-day period. The survival of the organisms was determined in a separate experiment by counting viable cells in whole-body homogenates, as described above.

\section{RESULTS}

\section{Effect of age on susceptibility of $H A M / 1 C R$ mice to $C$. fetus ss. jejuni}

Initially, 3- and 5-week-old mice were given $3 \times 10^{9} \mathrm{cfu}$ of $C$. fetus ss. jejuni either orally or by i.v. injection, but none of these mice developed diarrhoea and none died. When younger mice were challenged i.p. with $3 \times 10^{9} \mathrm{cfu}$ of $C$. fetus ss. jejuni strain 5636 , three of 201 -day-old and six of 20 7-day-old mice died within 10 days. This effect was particularly evident after the $C$. fetus strain was passaged five times in 5 -week-old mice; the organisms were isolated from the spleen at each passage before re-inoculation into uninfected mice.

In an attempt to define the influence of age on susceptibility, mice of various ages (1-35 days) were challenged i.p. with $(1 \cdot 25-10 \cdot 0) \times 10^{9}$ cfu of $C$. fetus ss. jejuni strain 5636. During a 10-day post-injection period, it was apparent that 7 -day-old mice were most susceptible; 32 of 40 died and the LD50 was $1.8 \times 10^{9} \mathrm{cfu}$ (table I). By contrast, the LD50 values for younger and older mice were significantly higher.

\section{Recovery of viable C. fetus ss. jejuni from whole body homogenates}

After i.p. injection of $(0.62-2.5) \times 10^{9} \mathrm{cfu}$ into groups of 7-day-old mice, pairs of animals were killed at $12-\mathrm{h}$ intervals and the numbers of viable campylobacters in whole-body homogenates were determined. After the injection of sub-lethal numbers

TABLE I

Susceptibility of HAM/1CR mice to intraperitoneal challenge with C. fetus ss. jejuni

\begin{tabular}{c|c}
\hline $\begin{array}{c}\text { Age of mice* } \\
\text { (days) }\end{array}$ & $\begin{array}{c}\text { LD50 (and 95\% confidence limits) } \\
\text { expressed in cfu }\left(10^{9}\right)\end{array}$ \\
\hline 1 & $8 \cdot 0(5 \cdot 0,12 \cdot 0)$ \\
3 & $4 \cdot 4(3 \cdot 3,5 \cdot 8)$ \\
7 & $1 \cdot 8(1 \cdot 3,2 \cdot 4)$ \\
14 & $2 \cdot 0(1 \cdot 5,2 \cdot 7)$ \\
21 & $15 \cdot 0(10 \cdot 0,23 \cdot 0)$ \\
35 & $>15 \cdot 0 \quad \ldots$ \\
\hline
\end{tabular}

* Each group contained 10 mice. The statistical analyses were done as described by Boyd (1956). In comparing LD50 values from two groups of mice, the difference is judged significant at the $\mathrm{P}=5 \%$ level if the LD50 of one group lies outside the $95 \%$ confidence limits of the other. 




FIG. 1.-The numbers of viable C. fetus ss. jejuni recovered from whole 7-day-old mouse homogenates after i.p. injection of $2.5 \times 10^{9}\left(\square-1.3 \times 10^{9}(\cdots)\right.$ and $0.62 \times 10^{9}(\Delta-\Delta) \mathrm{cfu} / \mathrm{mouse}$. The values plotted represent the mean counts of cfu isolated from the whole-body homogenates of two mice killed at each time.

of $C$. fetus ss. jejuni, the organisms were eliminated as shown in fig. 1. When the higher dose of $2.5 \times 10^{9} \mathrm{cfu}$ was injected, $<10 \%$ of the bacteria were recovered in the whole-body homogenates after $48 \mathrm{~h}$.

Susceptibility of 7-day-old mice to live and heat-killed C. fetus ss. jejuni strain 5636

The i.p. injection of $1 \times 10^{10} \mathrm{cfu}$ of $C$. fetus ss. jejuni into 7-day-old mice killed all the animals within $48 \mathrm{~h}$. When the same number of organisms was killed by heating at $56^{\circ} \mathrm{C}$ for $30 \mathrm{~min}$ before injection, 14 out of 15 of the challenged mice died. When the number of living or dead organisms in the injection dose was varied from $0.62 \times 10^{9}$ to $10 \times 10^{9} \mathrm{cfu}$, mortality rates were similar at the highest dose, $100 \%$ and $93.3 \%$ 




FIG. 2.-Probit mortality rates plotted against the number of living or dead $C$. fetus ss. jejuni cells in the i.p. challenge dose. The heavy arrows represent doses that gave $0 \%$ or $100 \%$ mortality and therefore probit values cannot be plotted. The LD50 value for living cells was $1.48 \times 10^{9} \mathrm{cfu}$ and for dead cells was $3.8 \times 10^{9}$ organisms. Probit values were calculated according to Boyd (1956).

respectively. With $2.5 \times 10^{9} \mathrm{cfu}, 86 \%$ of the animals were killed with live cells and $73.3 \%$ with dead cells. A plot of the probit of mortality against injection dose of living or dead C.fetus ss. jejuni showed parallel dose-response curves which suggests a similar mode of action (fig. 2), i.e., that both live and dead bacteria caused toxic death, with the live challenge reaching the lethal level after limited multiplication in vivo.

A suspension of $1 \times 10^{10}$ dead cells of $C$. fetus ss. jejuni strain 5636 in $0.1 \mathrm{ml}$ killed nine of 10 7-day-old mice after i.p. injection. On the other hand, the supernate from $1 \times 10^{10}$ cells $(0.1 \mathrm{ml})$, obtained after centrifugation of killed cells at $12000 \mathrm{~g}$ for $15 \mathrm{~min}$, failed to kill any of the challenged animals. Moreover, i.p. challenge with $0.1 \mathrm{ml}$ of the supernate from a sonicated suspension of $1 \times 10^{10}$ cells of $C$. fetus ss. jejuni centrifuged at $12000 \mathrm{~g}$ for $15 \mathrm{~min}$ did not cause the death of 7-day-old mice, whereas i.p. injection of $0.1 \mathrm{ml}$ containing the pellet of cell debris from $1 \times 10^{10}$ organisms killed $65 \%$ of the animals.

Enhancement of lethal toxicity of $C$. fetus ss. jejuni by ferric ammonium citrate

Intraperitoneal injection of 4-20 $\mu \mathrm{g}$ of iron in the form of ferric ammonium citrate into 7-day-old mice caused no apparent ill-effects, whereas $100 \mu \mathrm{g}$ killed $60 \%$ of the 


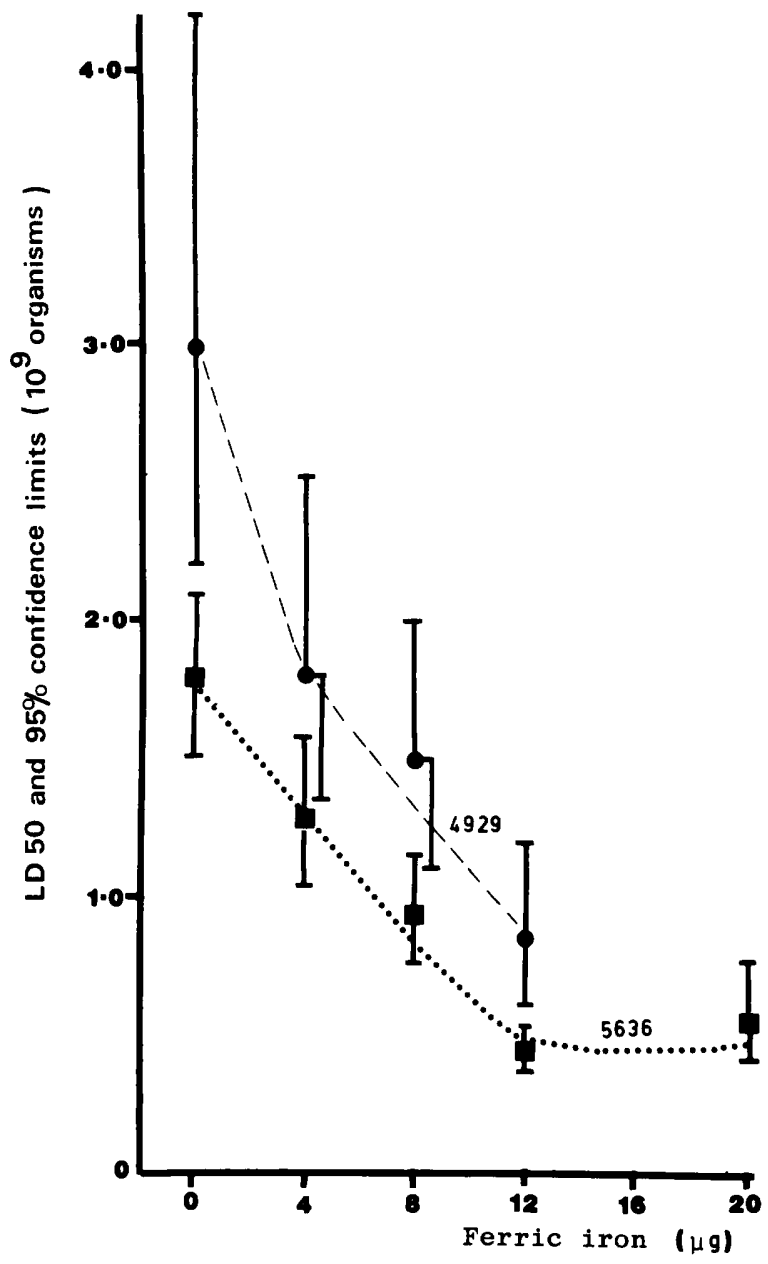

FIG. 3.-The effect of ferric iron on the lethality of $C$. fetus ss. jejuni strains 4929 and 5636 . The LD50 for strain 4929 was lowered from $3.0 \times 10^{9}$ to $8.5 \times 10^{8}$ cfu with $12 \mu \mathrm{g}$ ferric iron; with strain 5636 the same amount of iron lowered the LD50 value from $1.78 \times 10^{9}$ to $4.5 \times 10^{8} \mathrm{cfu}$ in 7-day-old mice. The LD50 values were calculated by the procedure of Boyd (1956).

animals. The incorporation of increasing amounts of ferric ammonium citrate

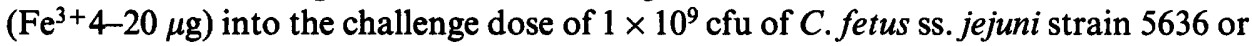
strain 4249 significantly decreased the LD50 values (fig. 3). The LD50 value of the $C$. fetus ss. jejuni strain 5636 suspension was $1.78 \times 10^{9} \mathrm{cfu}$, but this was lowered to $4.5 \times 10^{8} \mathrm{cfu}$ in the presence of $12.0 \mu \mathrm{g}$ of ferric iron. With C. fetus ss. jejuni strain 4249 , the LD50 value for the suspension alone was $3.0 \times 10^{9} \mathrm{cfu}$ and for the suspension plus $12 \mu \mathrm{g}$ of ferric iron it was $8.5 \times 10^{8} \mathrm{cfu}$.

The addition of ferric iron $40-120 \mu \mathrm{g} / \mathrm{ml}$ to $100 \mathrm{ml}$ of nutrient broth containing yeast extract and cysteine did not significantly increase the growth of $C$. fetus ss. jejuni. In experiments in which viable organisms were recovered from whole-body homogenates, the counts were consistently higher in animals given $12.0 \mu \mathrm{g}$ of ferric iron and 


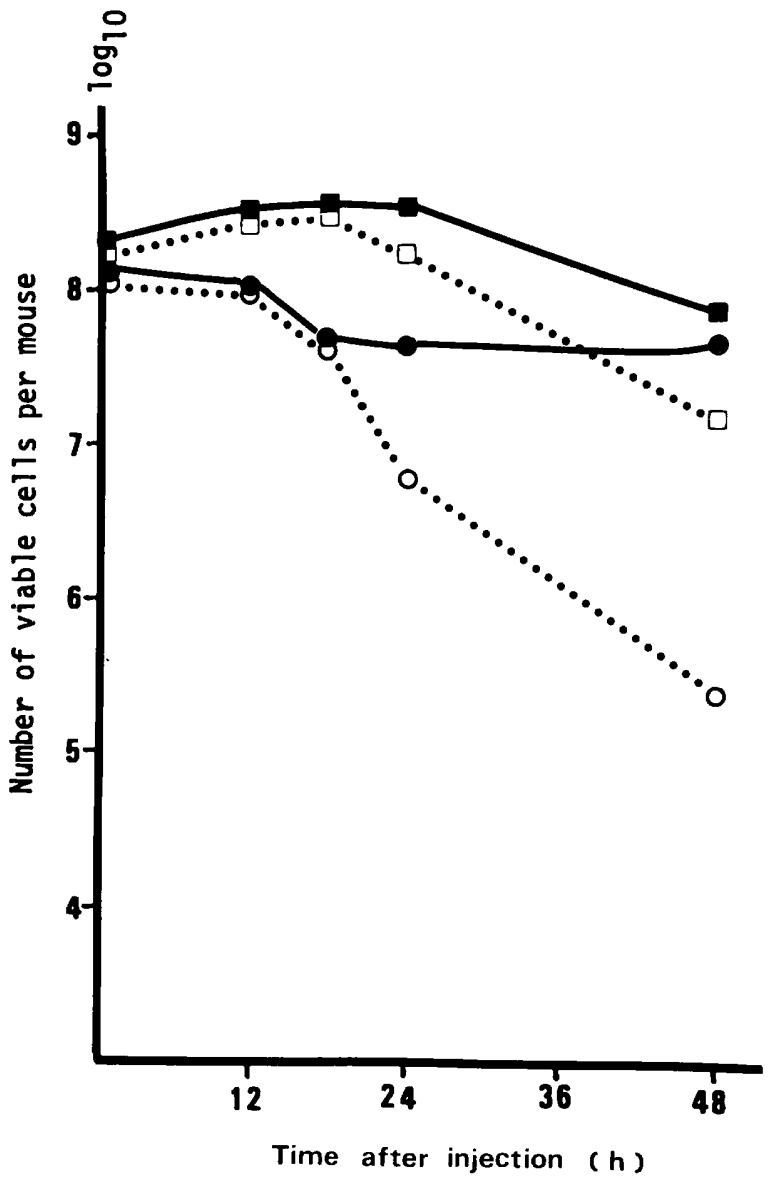

FIG. 4.- The effect of ferric iron on the reisolation of viable $C$. fetus ss. jejuni after i.p. injection into 7-day-old mice. Each value represents the mean viable count from two mice killed at each time. $0 \cdots 06.2 \times 10^{8} \mathrm{cfu}$ injected; $6.2 \times 10^{8} \mathrm{cfu}$ injected and $\mathrm{Fe}^{3+} 12.0 \mu \mathrm{g}$ injected $18 \mathrm{~h}$ later; … $6.2 \times 10^{8} \mathrm{cfu}$ and $\mathrm{Fe}^{3+} 12.0 \mu \mathrm{g}$ injected at time $0 ;-6.2 \times 10^{8} \mathrm{cfu}$ and $\mathrm{Fe}^{3+} 12.0 \mu \mathrm{g}$



C. fetus ss. jejuni i.p.; in some experiments, a two-fold $\log _{10}$ difference was noted. On the other hand, there was a progressive decrease in the viable counts in homogenates from 7-day-old mice challenged i.p. with the $C$. fetus ss. jejuni suspension alone. The elimination of bacteria from mice given 8-12 $\mu \mathrm{g}$ of ferric iron was delayed for at least 24 $\mathrm{h}$; then there was a reduction in the number of organisms recovered.

Similar elimination patterns in two groups of animals after i.p. challenge with $6.2 \times 10^{8} \mathrm{cfu}$ were obtained until $18 \mathrm{~h}$, when one group was given an injection of $\mathrm{Fe}^{3+}$ $12 \mu \mathrm{g}$ which retarded the elimination of $C$. fetus ss. jejuni (fig. 4). In addition, the elimination of organisms was less pronounced in animals given $12 \mu \mathrm{g}$ of ferric iron at time 0 and a further $12 \mu \mathrm{g}$ at $18 \mathrm{~h}$. The incorporation of $12 \mu \mathrm{g}$ of ferric iron into the inoculum did not increase the toxicity of heat-killed $C$. fetus ss. jejuni for the 7-day-old mice. 
The combined effect of heterologous lipopolysaccharide and ferric iron on C. fetus ss. jejuni

When 7-day-old mice were challenged i.p. with $25-400 \mu \mathrm{g}$ of Shigella flexneri lipopolysaccharide (LPS) the LD50 was $61.5 \mu \mathrm{g}(95 \%$ C.L. 39.7, 95.4) and in the presence of $12.0 \mu \mathrm{g}$ of ferric iron the LD50 was $46.6 \mu \mathrm{g}(95 \%$ C.L. 33.2, 65.5). The injection of $25 \mu \mathrm{g}$ of LPS did not cause the death of any animals, although sometimes there was some shivering and ruffling of the coats for $1-2 \mathrm{~h}$. Consequently, to avoid these effects, LPS was administered $4 \mathrm{~h}$ before the challenge with $(0.078-1 \cdot 3) \times 10^{9} \mathrm{cfu}$ of $C$. fetus ss. jejuni strain 5636. There was a 22-fold reduction in the LD50 value in the presence of $25 \mu \mathrm{g}$ of LPS. However, in animals given $25 \mu \mathrm{g}$ of LPS before challenge with $C$. fetus ss. jejuni and $12 \mu \mathrm{g}$ of ferric iron, there was a 66-fold reduction in the LD50 value when compared with the bacterial challenge alone (table II).

\section{TABLE II}

The effect of ferric ammonium citrate and heterologous S. flexneri LPS on the lethal toxicity of C. fetus ss. jejuni for 7-day-old mice

\begin{tabular}{l|c}
\hline \multicolumn{1}{c|}{ Nature of challenge* } & $\begin{array}{c}\text { LD50 (and 95\% confidence limits) } \\
\text { expressed in cfu }\left(10^{7}\right)\end{array}$ \\
\hline Bacterial challenge alone & $180(70,450)$ \\
$\mathrm{Fe}^{3+12 \mu \mathrm{g} \text { with challenge }}$ & $45(20,99)$ \\
LPS $25 \mu \mathrm{g}$ 4h before challenge & $8 \cdot 1(3 \cdot 4,19)$ \\
LPS $25 \mu \mathrm{g}$ 4h before, plus & $\mathrm{Fe}^{3+12 \mu \mathrm{g} \text { with challenge }}$ \\
\hline
\end{tabular}
jejuni.

* All groups of 20 mice were challenged i.p. with a dose in the range $(0.08-1 \cdot 3) \times 10^{9} \mathrm{cfu}$ of $C$. fetus ss.

\section{Discussion}

In an attempt to establish a model of campylobacter infection in the HAM/1CR mouse, initial experiments were done with intraperitoneal challenges in animals of different ages. Mice in the age range 7-14 days were significantly more susceptible than either 1-3-day-old animals or young adults ( $>21$-day-old). However, none of the animals examined post mortem showed signs of diarrhoea, and faecal pellets could be seen in the rectum, indicating that there had been no gross disturbance of normal bowel function. In a separate study viable organisms were recovered from the blood, liver and spleen up to 7 days after i.v., i.p. or oral administration to 3-5-week-old mice. Although there was evidence of a transitory period of bacterial multiplication, $C$. fetus ss. jejuni strains 4249 and 5636 were not recovered from the blood or spleen after $48 \mathrm{~h}$. The largest numbers of organisms were recovered from the liver, but by the seventh day after infection viable $C$. fetus ss. jejuni was not isolated $(\mathrm{Ng}, 1981)$. The rapid elimination of $C$. fetus ss. jejuni from the blood indicated that death of the 7-14-day-old mice was a consequence of the total number of bacteria in the initial inoculum and not of rapid in-vivo multiplication.

After the injection of smaller numbers of $C$. fetus ss. jejuni, recovery experiments from whole-body homogenates showed that the number of viable organisms decreased 
up to $48 \mathrm{~h}$. With larger challenge doses there was a slower rate of elimination which indicated some in-vivo multiplication, but this was insufficient to overcome the normal clearance mechanism. Although $90 \%$ of the C. fetus ss. jejuni challenge was eliminated after $48 \mathrm{~h}$ (fig. 1), the mice still died.

The resistance of 1- and 3-day-old mice may be associated with antibacterial factors such as lactoferrin or lysozyme from maternal milk. The phagocytic activity of reticuloendothelial cells in mice was shown to be well developed by 21 days (Benacerraf et al., 1954). Immunocompetence is related to the formation of antigen-recognising macrophages (Argyris, 1968) and this might explain the resistance of the older mice. Such cells are not well developed in young mice, and this may be an additional factor in the susceptibility of 7- and 14-day-old animals. It is interesting that a similar pattern of age susceptibility was observed with staphylococcal infection in mice (McKay and Arbuthnott, 1979).

The factor responsible for the death of the 7-day-old mice challenged with C.fetus ss. jejuni seemed to be endotoxin, as animals also died after the injection of similar numbers of heat-killed cells. Toxicity was related to the total number of heat-killed cells injected and this suggested that a critical quantity of endotoxin caused death of the young mice. Sufficient endotoxin was present in $5 \times 10^{9}$ organisms to cause death of 7-day-old mice within $24 \mathrm{~h}$. Although 7-day-old mice were shown to destroy $C$. fetus ss. jejuni organisms after sub-lethal challenges with fewer organisms, it seemed that there was some bacterial multiplication. However, when the critical amount of endotoxin had accumulated in the animal, death occurred.

The importance of iron in microbial infections is now well recognised (Bullen, Rogers and Griffiths, 1978; Bullen, 1981), as also is the fact that iron in host tissues may not be freely available to bacteria in an infection (Morgan, 1974). For instance, in cultures containing serum, there may be a bactericidal or bacteriostatic effect for some organisms. These effects can be reversed by saturating the iron-binding capacity of serum transferrin with $\mathrm{Fe}^{3+}$; in vivo the administration of enough ferric ammonium citrate to saturate the transferrin increased the lethality of Escherichia coli (Bullen and Rogers, 1969). The injection of 4-12 $\mu \mathrm{g}$ ferric iron produced a similar effect in 7-day-old mice challenged with strains of $C$. fetus ss. jejuni by i.p. injection.

Although many studies have examined the effect of $\mathrm{Fe}^{3+}$ ions, it is possible that $\mathrm{NH}_{4}^{+}$ions might have an effect, so it would be interesting to examine the effects of a series of ferric and ammonium compounds on C.fetus ss. jejuni. The citrate is unlikely to be important because considerable levels are normally found in blood (Wolcott and Boyer, 1948).

The precise mechanism whereby the ferric iron and endotoxin prevents elimination of campylobacter organisms is complex and uncertain. Saturation of iron-binding proteins, e.g., transferrin and lactoferrin, could leave some free $\mathrm{Fe}^{3+}$ and thus allow growth of the bacteria. Macrophages will readily remove ferric-lactoferrin complexes from the circulation (Van Snick, Masson and Heremans, 1974). The results presented here also suggest that the ferric iron did not impair phagocytic cell function because elimination of organisms still occurred (fig. 4). It was concluded that the recovery curves represented the balance between limited bacterial multiplication and phagocytosis.

Hypoferraemia may occur during infection and may enhance non-specific resistance to bacteria (Cartwright et al., 1946). The addition of iron as ferric 
ammonium citrate may reverse this situation. In addition, the injection of $10 \mu \mathrm{g}$ of $E$. coli LPS caused hypoferraemia in adult mice after $12 \mathrm{~h}$ and then the serum iron appeared to increase progressively (Baker and Wilson, 1965). Kampschmidt and Upchurch (1962) found that $100 \mu \mathrm{g}$ of LPS caused a maximum decrease in serum iron 8-16 $\mathrm{h}$ after injection in rats. Endotoxin may induce a non-specific resistance to infection with some bacteria. In the present study the injection of $S$. flexneri LPS $4 \mathrm{~h}$ before challenge with $C$. fetus ss. jejuni significantly increased the mortalities. Some decrease in serum iron could be expected after $4 \mathrm{~h}$, but the decrease would be most marked after $24 \mathrm{~h}$ with a return to normal values after $48 \mathrm{~h}$ (Kampschmidt and Upchurch, 1964). The observed increase in susceptibility of the young 7-day-old mice to $C$. fetus ss. jejuni in the presence of LPS might be due to an endotoxin-induced neutropaenia. Sub-lethal doses of $0.62 \times 10^{9} \mathrm{cfu}$ of $C$. fetus ss. jejuni 5636 caused the death of all animals in the presence of the heterologous LPS $2.5 \mathrm{mg} / \mathrm{kg}$ live weight. The LD50 was reduced from $1.8 \times 10^{9} \mathrm{cfu}$ without LPS to $8 \cdot 1 \times 10^{7} \mathrm{cfu}$ with LPS. The combined effects of $S$. flexneri LPS and ferric ammonium citrate reduced this even more to $2 \cdot 7 \times 10^{7} \mathrm{cfu}$. It seems that competition between the mouse and $C$. fetus ss. jejuni for iron is only one factor in the endotoxin-induced death. The influence of the $C$. fetus ss. jejuni LPS on the balance between free and bound iron remains to be examined.

In adult immunocompetent mice, it seems likely that phagocytic clearance overcame the campylobacter challenge and a lethal dose of endotoxin did not accumulate. On the other hand, in 7-day-old mice given sub-lethal doses of C.fetus ss. jejuni together with ferric iron, endotoxin accumulated more rapidly and death occurred before the phagocytic cells could remove the organism.

Recently, Blaser et al. (1983) reported that adult HA-1CR mice given $1 \times 10^{8} \mathrm{cfu}$ of C. fetus orally were bacteraemic after $10 \mathrm{~min}$. These results were presented in a way that makes it difficult to assess whether bacterial multiplication occurred or not. These authors agreed that no experimentally infected adult mice showed overt illness or died. In the present study, the examination of whole body homogenates from young mice indicated that there is a reduction in numbers of viable organisms with time and elimination of organisms; this agrees with the findings of Field, Underwood and Berry (1982). However, it does seem that the HAM/1CR mouse is an unsuitable model for studies of campylobacter infection.

\section{REFERENCES}

Argyris B F 1968 Role of macrophages in immunological maturation. Journal of Experimental Medicine 128:459-467.

Baker P J, Wilson J B 1965 Hypoferremia in mice and its application to the bioassay of endotoxin. Journal of Bacteriology 90:903-910.

Benacerraf B, Halpern B N, Biozzi G, Benos S A 1954 Quantitative study of the granulopectic activity of the reticulo-endothelial system. III. The effect of cortisone and nitrogen mustard on the regenerative capacity of the R.E.S. after saturation with carbon. British Journal of Experimental Pathology 35:97-106.

Blaser M J, Duncan D J, Warren G H, Wang W-L L 1983 Experimental Campylobacter jejuni infection of adult mice. Infection and Immunity 39:908-916.

Boyd W C 1956 Fundamentals of immunology. Interscience Pub. Inc., New York.

Bullen J J 1981 The significance of iron in infection. Reviews of Infectious Diseases 3:1127-1138.

Bullen J J, Rogers H J 1969 Bacterial iron metabolism and immunity to Pasteurella septica and Escherichia coli. Nature 224:380-382. 
Bullen J J, Rogers H J, Griffiths E 1978 Role of iron in bacterial infection. Current Topics in Microbiology and Immunology 80:1-35.

Butzler J-P, DeKeyser P, Detrain M, Dehaen F 1973 Related vibrios in stools. Journal of Pediatrics 82:493-495.

Butzler J-P, Skirrow M B 1979 Campylobacter enteritis. Clinical Gastroenterology 8:737-765.

Cartwright G E, Lauritsen M A, Humphreys S, Jones P J, Merrill I M, Wintrobe M M 1946 The anemia of infection. II. The experimental production of hypoferremia and anemia in dogs. Journal of Clinical Investigation 25:81-86.

Field L H, Underwood J L, Berry L J 1982 Colonization of the digestive tract of adult mice with Campylobacter fetus ssp. jejuni. Abstracts of the Meeting of the American Society of Microbiology 42.

Guerrant R L, Lahita R G, Winn W C, Roberts R B 1978 Campylobacteriosis in manpathogenic mechanisms and review of 91 bloodstream infections. American Journal of Medicine 65:584-592.

Hallett A F, Botha P L, Logan A 1977 Isolation of Campylobacter fetus from recent cases of human vibriosis. Journal of Hygiene 79:381-389.

Jackson J F, Hinton P, Allison F 1960 Human vibriosis. Report of a patient with relapsing febrile illness due to Vibrio fetus. American Journal of Medicine 28:986-994.

Jones F S, Orcutt M, Little R B 1931 Vibrios (Vibrio jejuni sp.) associated with intestinal disorders of cows and calves. Journal of Experimental Medicine 53:853-863.

Kampschmidt R F, Upchurch H F 1962 Effects of bacteria endotoxin on plasma iron. Proceedings of the Society for Experimental Biology and Medicine 110:191-193.

Kampschmidt R F, Upchurch H F 1964 Effect of endotoxin upon total iron-binding capacity of the serum. Proceedings of the Society for Experimental Biology and Medicine 116:420-422.

Lambert M E, Schofield P F, Ironside A G, Mandal B K 1979 Campylobacter colitis. British Medical Journal 1:857-859.

Levy A J 1946 A gastro-enteritis outbreak probably due to a bovine strain of Vibrio. Yale Journal of Biology and Medicine 18:243-258.

McKay S E, Arbuthnott J P 1979 Age-related susceptibility of mice to staphylococcal infection. Journal of Medical Microbiology 12:99-106.

Mandel A D, Ellison R C 1963 Acute dysentery syndrome caused by Vibrio fetus. Journal of the American Medical Association 185:536-538.

Manninen K I, Prescott J F, Dohoo I R 1982 Pathogenicity of Campylobacter jejuni isolates from animals and human. Infection and Immunity 38:46-52.

Middelkamp J N, Wolf H A 1961 Infection due to a 'related vibrio'. Journal of Pediatrics $59: 318-321$.

Miles A A, Misra S S, Irwin J O 1938 The estimation of the bactericidal power of the blood. Journal of Hygiene 38:732-749.

Morgan E H 1974 Transferrin and transferrin iron In: Jacobs A, Worwood M (eds) Iron in biochemistry and medicine. Academic Press, London, pp 29-71.

Ng F K P 1981 Studies on Campylobacter fetus subspecies jejuni. Ph.D. thesis, University of Glasgow.

Philip D A, Tilton R C 1977 Campylobacter and Spirillum. In: Seligson D (ed) CRC Handbook Series in Clinical Laboratory Science.

Prescott J F, Karmali M A 1978 Attempts to transmit Campylobacter enteritis to dogs and cats. Canadian Medical Association Journal 119:1001-1002.

Robinson B L 1978 Infection of humans with Campylobacter fetus. Canadian Medical Association Journal 118:1087-1088.

Ruiz-Palacios G M, Escamilla E, Torres N 1981 Experimental Campylobacter diarrhea in chickens. Infection and Immunity $34: 250-255$.

Skirrow M B 1977 Campylobacter enteritis: a "new" disease. British Medical Journal 2:9-11.

Smibert R M 1978 The genus Campylobacter. Annual Review of Microbiology 32:673-709.

Van Snick J L, Masson P L, Heremans J F 1974 The involvement of lactoferrin in the hyposideremia of acute inflammation. Journal of Experimental Medicine 140:1068-1084.

Wheeler W E, Borchers J 1961 Vibrionic enteritis in infants. American Journal of Diseases of Children 101:60-66.

Wolcott G H, Boyer P D 1948 A colorimetric method for the determination of citric acid in blood and plasma. Journal of Biological Chemistry 172:729-736. 